\title{
A CONSERVATIVE REVOLUTION: THE ELECTORAL RESPONSE TO ECONOMIC CRISIS IN IRELAND
}

Michael Marsh (Trinity College Dublin) and Slava Mikhaylov (University College London)

\begin{abstract}
The 2011 election in Ireland was one of the most dramatic elections in European postwar history in terms of net electoral volatility. In some respects the election overturned the traditional party system. Yet it was a conservative revolution, one in which the main players remained the same, and the switch in the major government party was merely one in which one centre right party replaced another. Comparing voting behaviour over the last three elections we show that the 2011 election looks much like that of 2002 and 2007. The crisis did not result in the redefinition of the electoral landscape. While we find clear evidence of economic voting at the 2011 election, issue voting remained week. We believe that this is due to the fact that parties have not offered clear policy alternatives to the electorate in the recent past and did not do so in 2011.
\end{abstract}




\section{Introduction}

The announcement of a 'bailout' for the Irish state by the IMF/EU/ECB in November 2010 marked a critical point in the fortunes of the Irish economy and the state's fiscal problems which had been signalled to be in crisis two years earlier when the government felt it necessary to provide a blanket support to the Irish banks. Cuts had been made in many programmes and the pay of public sector workers had been reduced by an average of about 20 per cent. Unemployment soared, from 4.5 per cent at the time of the 2007 election to 14.5 per cent in early 2011. Even as the Dáil (lower house of parliament) approved the terms of the loan, under which stern targets with relation to taxation and spending were set and public policy would be monitored closely until the money was repaid, the government was disintegrating and an election followed soon in February 2011. The result was certainly dramatic: the major party of government and dominant force in the party system, Fianna Fáil (FF), was relegated to third place; the minor partner, the Green Party, lost all its seats; and Fine Gael (FG) became the largest party for the first time and formed a government with the Labour Party, which had almost doubled its vote. Measured in terms of net electoral volatility (the Pedersen index) this was one of the most dramatic elections in European post-war history, and it provided the biggest turnaround in party fortunes that had been seen without the intervention of a significant new party (Mair 2011). Yet it was arguably a conservative revolution, one in which the main players remained the same, and the switch in the major government party was merely one where one centre right party replaced another.

This can easily be interpreted as a classic case of economic voting, in which voters punished those responsible for the obvious decline in their collective fortunes, with the added element of public anger at the degree of mismanagement that had taken place (Key 1966; Powell and Whitten 1993). We could also see it as further evidence that Ireland fits well into the modern characterisation of political competition as 'valence' politics (Marsh et al. 2008; Stokes 1963; Clarke et al. 2009 ), centred on the economy. This argues that voters will choose the parties seen as most competent to deal with the main - typically economic - issues, and the voters had lost faith in FF as the crisis unfolded. Indeed, poll evidence shows FF support declining sharply as successive stages of the crisis seemed to demonstrate the ineptitude of the government 
before the more objective indicators were there to confirm economic decline (Marsh and Mikhaylov 2012). Support went to the obvious alternative, FG and Labour, who had provided the (only) alternative government several times since 1948 but were untainted by responsibility, having been in opposition since 1997.

Yet there were expectations in some quarters, and these have echoes internationally, that the crisis might provide a change in the bases of electoral decision-making. This occasion could have been one in which 'policy' choices - and by that we mean choices about how to deal with the crisis - could have been more prominent than they were in recent elections, when the issues around economic management were apparently less urgent and less discussed. The crisis arguably exposed the neo-liberal model of economic management, one that was followed by governments of both centre left and centre right across Europe for decades, as having fundamental weaknesses. In consequence there might have been some clear shift away from its tenets and at least a break-up of that consensus. Different groups might define the crisis in different ways - perhaps as a fiscal problem, or by highlighting unemployment - and they may also have different solutions, such as raising taxes on the rich, or cutting expenditure on social welfare. This could have encouraged a sharper left-right divide. Certainly parties of the 'left' did unprecedentedly well, winning arguably 31 per cent of the vote, ${ }^{1}$ but whether this signified that voters were making an explicit choice of a policy alternative, rather than simply running to anyone but $\mathrm{FF}$, is far less obvious.

While crises such as the Irish one might shake people and institutions out of traditional, almost habitual patterns of behaviour, it is important to acknowledge that such patterns may also be hard to dislodge. There are at least a couple of features of Irish politics that might constrain change. One is the 'personal vote', the following that candidates have which may be independent of party; more generally, this includes the importance of candidate relative to party (Carty 1983; Komito and Gallagher 2010; Marsh 2007). While the appeal of particular candidates obviously did not save Fianna Fáil from an electoral drubbing, it may still be the case that voters' concerns to pick a candidate may inhibit a more ideological politics (e.g. Sacks 1976). A second is the behaviour of the parties. Arguably, for voters to change, parties have to lead the way. In the past, parties have generally obscured rather than highlighted ideological differences. We will explore the extent to which this was different in 2011. 
These are the primary features of the election that will be explored in this paper. We will start by looking at the vote in terms of punishment and reward, and consider the importance of blame attribution. We look at what voters thought about the crisis: who was to blame, and who could do a better job in the future. FF did very badly, but how far can the economic crisis explain the scale of the defeat, and the victory or FG and Labour? We will also consider a broader 'valence' model such as those advanced by Clark et al. (2009) in which leader and parties are judged in terms of competence to govern. We will then explore how far voters seemed to see this as an election not simply about replacing the government, but of making a choice about future policy directions, with a cleavage along typical economic left-right lines.

\section{Who was to blame?}

There can be little doubt that voters held the government responsible for the crisis, although that is not to say that blame lay solely with that body. The government claimed that much of the reason for the sharp economic downturn and consequent fiscal crisis was external: the collapse of Lehman Brothers and the consequent turmoil in international markets. Independent inquiries set up by the government, but whose remit did not extend to the period of the bank bailout, certainly identified lax regulation as well systemic failures in the Department of Finance, while criminal charges have now been brought against some of the leaders of one of the banks. The Irish Election Study of $2011^{2}$ sought to establish the distribution of culpability across various actors. Table 1 shows the results.

\section{$<<$ INSERT TABLE 1 ABOUT HERE $>>$}

While 'bankers' were almost universally accorded a share of the blame, government bodies and the government itself were also held very culpable by a huge majority of voters, almost 80 per cent seeing the government as 'very' or 'extremely' responsible, and almost 90 per cent feeling the same way about the public servants who were in charge. In contrast, only 60 per cent blamed the international economic situation to the same degree, while the EU and, even more so, Euro membership was relatively 
innocent. We normally expect responsibility to be conditioned by partisanship, and indeed there is something of this in this data, but only 1 per cent of all voters absolved the government completely and only 8 per cent saw them as less than even 'moderately' responsible. FF voters were more likely than others to blame civil servants, and less likely to blame FF as strongly as other voters, but generally these attributions are at most weakly related to vote. Partisanship does not explain who voters think is most to blame. The key point about this list is that voters tended to place more blame at the feet not of international actors and systems but of domestic actors, who either were, or should have been, better regulated by government.

In previous elections in this century there was a greater difference of opinion among voters when it came to blaming, or crediting governments, and also more variation in perceptions of the government's economic record. Table 2 shows the voters' judgment of the record, the attribution of credit/blame and also considerations as to whether another government might have done better.

\section{$<<$ INSERT TABLE 2 ABOUT HERE $>>$}

The FF led government was re-elected in 2002 and 2007 (after which the Greens were added to the coalition) with most people seeing the economy as improving, majorities seeing the government as responsible and relatively few thinking the alternative would have done better. This is not surprising: growth was rapid for much of the period, and unemployment had fallen to an unprecedentedly low level, while employment had soared. In 2011, in contrast, with growth stalled, employment falling and unemployment rising rapidly, almost everyone thought the economy had deteriorated considerably, almost everyone blamed the government and this time a sizable minority thought FG and Labour would have done a better job.

A simple multinomial logit model regressing vote on just the variables displayed in Table 2, with added controls for party identification, performs almost equally well in all three years, with pseudo $\mathrm{R}^{2} 0.20,0.20$ and 0.17 respectively. ${ }^{3}$ Table 3 shows the marginal effects ${ }^{4}$ for each of the four main parties in $2011 .{ }^{5}$ The model works best, as one might expect, in differentiating FF, the dominant government party. All variables are highly significant in 2011, with the economy also having its strongest effect in 
that year. The economy does less well in differentiating between the opposition parties. The key factor seems to be whether FG/Labour would have done better: those who thought so were more likely to vote FG and to a lesser extent Labour, while those who did not opted for SF. Those more reluctant to give the government credit in 2002 and 2007 also are more likely to vote FG. If we model the choice as simply that between FF and FG, pseudo $\mathrm{R}^{2}$ rises to 0.32, 0.28 and 0.32 across 2002-2011, with all effects highly significant in 2011 and the credit/blame effect particularly marked, adding 17 per cent to the $\mathrm{FG}$ share of the combined FG/FF vote. ${ }^{6}$

\section{$<<$ INSERT TABLE 3 ABOUT HERE $>>$}

All this suggests that the economic voting model helps to tell us why FF did so badly in 2011. Times were bad, and there is evidence that voters blamed FF more when times were bad than they credited the party when times were good. The model also helps to account for why FG and to a lesser extent Labour capitalised, but not why voters chose one of them rather than the other, and it is even less successful at explaining the change elsewhere in the system, nor why the huge number of voters who deserted FF ended up where they did. ${ }^{7}$

It has been argued that assessments of leaders play a critical role in voters' electoral choice, although many argue that the effects, while they may be critical in a close election, are relatively small in the context of a party's overall vote. It is of course problematic to separate leader and party evaluations, since each may be contaminated by the other (see Clarke et al. 2009; Curtice and Holmerg 2005; W Miller and Shanks 1996). Keeping this in mind we explored the added value of leader evaluations for the models run above. The question items used here all asked voters to say how good a leader was at "running the country", using a 0-10 scale. This was asked of four party leaders in 2011, those of FG, FF, Labour and SF, but only of a subset of these in previous studies. The FG leader was rated more highly than the FF leader only in 2011, but even then his lead was much smaller than the FF lead in 2002 and 2007.

If we add these leader variables to the first regression model discussed earlier, explained variance for 2011, using all four leaders, rises from .17 (see Table 3) to $28 .{ }^{8}$ Adding just the FF and FG leaders, it also improves in each of the three years. 
The leaders' marginal effects are generally all significant, adding up to 6 per cent (in the case of Labour in 2011) to a party's vote. The main point here, however, is not whether leaders mattered, or how much they mattered, but to show that even using a more inclusive understanding of valence politics (on the economy) containing parties and leaders, the 2011 election looks much like that of 2002 and 2007. The models are really no more, or less, effective in explaining voting in 2011 than they are in previous years. FF lost because it and its leaders were seen to have done a very poor job, and FG and Labour were a better bet for the future, the converse of 2002 and 2007.

\section{Evidence for issue based voting}

So far the evidence suggests that valence politics, at least with respect to the economy, were no less important in 2011 than in previous years. We now move on to look at whether or not judgements about competence were supplemented by concerns about the direction of policy, most notably in relation to the economy, but also the substitution of non-economic issues for economic ones. On this second point the salient issue of the 2011 election as measured directly by surveys was the economy, but within that fairly broad concern voters did emphasise different aspects of the overall problem. Asked to name the two most important issues to them personally, 58 per cent mentioned some aspect of the crisis, and 54 per cent a more specific economic issue. Twenty six per cent highlighted the fact that the government or the system had let them down, but another 26 per cent mentioned another (essentially non economic) issue, the most frequently cited being the health system. Overall, a massive 86 per cent of voters mentioned either the crisis or an economic issue. With respect to particular economic issues, most (43 per cent) highlighted job creation. Perhaps this might plausibly be seen as indicating a concern for the policies of growth over those of austerity. Just over 50 per cent of Labour and SF supporters talked about jobs, as against 40 per cent of FF voters and just 37 per cent of FG voters. More generally, however, the issues mentioned by each voter generally relate weakly, if at all to electoral choice, and even job creation explains less than 1 per cent of the variance in vote choice. All parties' manifestos recognised job creation as necessary, but there is also some evidence from opinion polls during the campaign that Labour outperformed 
FG on the jobs issue, while on the deficit and the banking issue FG was most capable (Marsh and Cunningham 2011, 188-189). Dealing with the crisis required policies to fill the hole in the public finances. Job creation, all agreed, was one part of that, although the parties on the left, like the trade unions, saw a stronger role for government in achieving it.

More generally, the choice was one of increasing state income and/or reducing expenditure, the tax/ spend trade-off that typically separates left and right. The terms of the IMF/EU/ECB deal were set by the time of the election, and only SF - perhaps knowing it would be in opposition anyway - promised to tear up the agreement. There were differences between parties over the time scale for eliminating the deficit with trade unions and SF setting a longer time horizon. FG and Labour (and SF) differed on the balance of tax increases and expenditure cuts, with SF arguing for more taxes on the most well off, FG resisting almost any increase in direct taxation and Labour looking to cut the deficit using tax increases and spending cuts equally (Suiter and Farrell 2011, 36-38).

Two questions were asked in the election study about this trade-off. One was the conventional increase tax/cut spending item and the other, in the spirit of the times, counter posed tax increases and small cuts with no tax increases and larger cuts. ${ }^{9}$ Both items employed a 0-10 scale. The distribution of responses was almost identical, with a fairly even balance around a high peak at 5, although the correlation between the two sets of responses was only a little over 0.5 .

Figure 1 shows the changing distribution of responses to a conventional question on this trade-off. There is a leftward bias to the distribution in 2011, but this is actually less pronounced than in previous years. In particular, very few placed themselves on the extreme left point; 2011 saw a marked increase in placing themselves at the sixth and seventh point. In 2007, with all parties offering to reduce taxation (still further), there was arguably less attention given to this trade-off, and more attention to areas that required more spending, notably health. Property taxes were proving the state with a comfortable surplus. Nor did the major parties discuss increasing taxes in 2002. The tax cuts in the previous decade were popular; rather Labour and FG each focussed on improving the quality of public services, to be paid for in a painless 
fashion. We might expect that 2011 would see a significant link between a voter's position on this broad issue, and vote, however weak this might have been earlier. ${ }^{10}$

\section{$<<$ INSERT FIGURE 1 ABOUT HERE $>>$}

Using this and several other measures of economic policy preference to model vote suggests only a tenuous link between such preferences and party choice in any of the years covered by the Irish election studies. Marginal effects from a multinomial logit regression, also including partisanship are shown in Table 4.

\section{$<<$ INSERT TABLE 4 ABOUT HERE $>>$}

Two points are very clear. The first is that these have a weak relationship with vote choice. The second is that this applies in 2011 as it did in 2002: there is no evidence of a closer link in 2011 despite the crisis and salience of the underlying issues. We would expect to see largely positive marginal effects for the centre right parties, FF and FG, and negative ones for the centre left and left parties, Labour and SF. Marginal effects are all small, even allowing for the fact that these are 11 and 7 point scales. The tax/spend issue has little significance, with only SF in 2011 showing a marginal effect at .05, and in the expected, negative direction (favouring higher taxes). Regulation seems more important in 2011: again, this has the unexpected sign for FF, and is not significant for SF. The public/private ownership item, available only in 2011, has no significant marginal effects. Finally, only one of the two measures capturing attitudes to equality has any significant effects, with Labour and SF voters (the latter only in the setting with a rephrased 2011 tax/spend question) disagreeing that there is nothing wrong with some being a lot richer than other, while FF and FG voters agree. This item is perhaps the most effective discriminator between the parties of the left and those of the right, but only in 2011. The equality items were previously significant for SF in 2007. Overall then, there is little here to suggest any of those issues that we typically see as providing the substance of left right debate, at least as measured here, had much impact on voting choice and no sign that they had more effect in 2011. 
However, if we move away from such issue questions and look simply at voters' own reported positions on a left-right scale, there does seem to be a much stronger relationship with vote choice. Figure 2 shows changes in the left-right self-placement distribution over time. In 2011 voters seem to have moved slightly to the right, with less than one third placed on the mid point. Essentially the change is a net shift of about 10 per cent of voters from point 5 to point 6 .

\section{$<<$ INSERT FIGURE 2 ABOUT HERE $>>$}

More important for our purpose here is how this translated into party choice, particularly as the 'left' performed better in 2011 than previously. Adding this assessment to the regression that underlies Table 4 provides evidence to suggest that self-placement is associated very significantly with voting, although there is no consistent evidence of a strengthening effect. It is stronger for FG in 2011 (0.054***, as against 0.008 and 0.011 in 2002 and 2007 respectively) and SF (-0.024*** as against $-0.009^{* *}$ and -0.004 in 2002 and 2007) but not for Labour (consistently left), or FF (consistently right). ${ }^{11}$ These effects, while generally significant, and always so in 2011, are still pretty modest ones. The left, in broad terms, is more obviously separate from the centre right parties, but looking at where voters of the different parties are now placed there is little evidence of much of a shift to the left.

Table 5, which shows how voters place both themselves and each party, suggests that the average voter for each of the parties has moved to the right since 2002 and 2007, and even that of SF has remained in the same position as 2007. The shift is particularly striking in the case of FG and Labour. Of course, both parties increased their vote significantly, but an influx of new voters does not explain the change, as those who claimed to have voted for each of those parties in 2007 are now also to the right of the voters of 2007. There was certainly no shift to the left, nor was there any obvious polarisation within the system, and on the economic dimensions the shifts were, if anything, in a rightward direction. 
We suggested that the view that voters might choose parties in 2011 based on tax/spend preferences had some plausibility, even if the evidence suggested that this calculus was not something that approximated to the thinking of many voters. The evidence is much better when we see voter ideology in more general terms, and while the signs that left-right voting might be intensifying are flimsy, they are not inconsistent with this view. However, there are anomalies; voters seem to have moved to the right as more of them voted for parties on the left, while those who did support left wing parties saw them as more right wing than did supporters in 2002 and 2007!

A further problem is that what voters mean by left and right is, at best, unclear. Voters have traditionally resisted such direct left-right self-placement measures, opting for the middle point (or the apparent middle point on a 10 point scale) or giving no response (Inglehart and Klingemann 1976; Sinnott 1995), suggesting that the concept was not familiar to many. In 2011 only about 13 per cent of voters could not place parties on a left right scale, and slightly more, 16 per cent, were unable to place themselves, which suggests more familiarity with the terms than was the case 40 years ago. More importantly, previous analysis has suggested that the Irish electorate tends not to associate equality with public enterprise and management, two elements of left-right ideology closely linked elsewhere (Kennedy and Sinnott 2006). Neither of these traditional indicators makes much of a contribution to explaining vote choice. Nor do they predict left-right self-placement very well! A simple test is the regression of self-placement on the tax/spend and regulation items above, plus two items tapping attitudes to inequality. ${ }^{12}$ The tax/spend preferences are significantly associated with left right only in 2007, although the 2011 reformulation is also significant at the even more marginal .10 level. Regulation is related consistently to self-placement (apart from 2007), and attitudes to private ownership are not significant at all. The items on inequality are also consistently associated with self-placement. Altogether though, these four indicators explain little variance in voters' positioning; we do not explain more than $4 \%$ of the variance. ${ }^{13}$ The highest explained variance is achieved in 2007. ${ }^{14}$ Of course it is possible that left right self-placement is not about economic or even equality issues as much as it is about other issues, such as a broadly religious vs. a secular view of society. Indeed, when an item asking whether or not God exists is added to the regression it out performs all other items and more than doubles the variance explained. Party support explains a lot more than economic, or religious 
factors, raising the possibility that placement may be better seen as a consequence rather than as a cause of vote choice (see also Marsh et al. 2008).

\section{Parties and candidates}

One factor commonly seen to inhibit issue-based representation is the importance of individual candidates to voters, and the fact that candidate appeal is rooted in parochial activities and concerns. Such attitudes might be a factor in obscuring the sort of relationships we have been exploring here, and that the 'clientelist' mode of politics which sustains the importance of candidate is one which inhibits the development of (national) issue centred politics, particularly around a left right economic cleavage (e.g. Higgins 1982; Sacks 1976). One response to the crisis could have been to direct attention away from merely local concerns and onto national ones. Anecdotal evidence from the campaign 'doorsteps' and earlier suggests some change. A senior FG politicians explained to one author at the start of the crisis that he was being told by supporters that he belonged in Dublin, sorting out the country, rather than holding 'clinics' in his constituency; a senior Labour politician reported that he was being asked during the campaign to discuss solutions to the debt crisis rather than what could be done about local potholes in the road. Would 'policy' trump 'looking after the constituency' in 2011?

Assessing the weight of candidates and parties in the vote is far from being straightforward, as support for each almost certainly spills over to the other. Parties gain support from running a 'good' candidate, but the party label influences the way voters see that candidate. Parties certainly cultivate promising candidates, whether or not they have a long history in the party, and will often nominate those with close family ties to former incumbents, thus combining candidate and party assets. Respondents in the election studies were asked whether party or candidate was most important in their vote. The results show a striking change from 2002-7 to 2011: from almost 60:40 emphasising the candidate in 2002-7, the weightings are almost exactly reversed in 2011. It is also notable that FF voters were now more likely to emphasise the candidate and FG voters less likely to do so. Overall this ties in somewhat with campaign polls, which seemed to show that voters stressed 'policy' more than in past 
years, and - though evidence here is more varied - placed less emphasis on picking a candidate to serve the constituency (Marsh and Cunningham 2011, 184-186). ${ }^{15}$

However, there is little sign that the more party-centred voter is any more likely to behave ideologically. There are only modest differences between party and candidatecentred voters in model fit. ${ }^{16}$ This seems on the face of it a curious result. While questions might be asked of the measure of party centredness here (but see fn 15) the fact remains that overall the ideological model fits poorly.

One further reason for that could lie in the parties and how they present themselves rather than with concerns of the voters. We have referred in passing to the stances taken by parties in the 2011 election, but we can now look at this more systematically, comparing position in 2011 to those in earlier years.

We used the data from the Manifesto Project for the elections since 1992 to 2011. Following Lowe et al. (2011) we rescaled the data using the empirical logit transformation that better captures the characteristics of underlying data, dynamic movement of parties on the dimensions of interest over time, and spatial politics assumptions about the range of ideal points (for details see also Benoit et al. 2012). We will look here at just three things: State involvement in economy ${ }^{17}$, State-provided services ${ }^{18}$ and finally, the general left-right dimension ${ }^{19}$. In each case we will show results for the positions of parties and also for the importance of the issue. What we are looking for here is evidence of a change in the 'supply side' in 2011, an indication that on economic issues in particular, as well as in broader left right terms, the electorate was offered a sharper choice in this election than previously, which might have provided the voters with a clearer definition of the differences between the parties. We are also interested in whether there is any substance behind the apparent rightward shift by voters evident in the earlier analysis, particularly around Table 5 and Figure 2.

The dimension of state involvement in economy captures the balance between market orthodoxy and liberalism on the right and higher involvement of the state in running the economy and supporting the welfare state on the left. Figure 3 (panel A) shows the positions of main parties on this dimension, and the importance of the dimension to the electoral platforms of the parties. The results correspond to conventional 
understanding of positions of Irish parties on the economic dimension, with FG and FF being pretty close to each other, Labour being further to the left outflanked only by SF. At the 2011 elections there appears to be a reversal of a long-term trend leftward by FF and FG, with the movement to the right by all four parties (albeit Labour started off on that trend already after the 2002 election). The importance of that dimension has grown for FF, FG, and Labour since 2002. It also appears that, positionally, three of the four parties are close to one another, and as close in 2011 as at any other time in the period covered. In other words, there was no obvious movement by the parties to provide any sharper definition of left and right in these terms in 2011.

Much the same is true on the State-provided services dimension. Panel B of Figure 3 provides party positions and importance of this dimension for parties. This dimension provides information drawn from the nature of references to welfare state and education limitations as opposed to expansion. Again we see a rightward move in 2011 with the three largest parties as close as at any time since 1992. Only SF provides a contrast. The importance of this issue appears to have declined slightly in 2011, more sharply for FF.

Finally, Panel C of Figure 3 shows an overall left-right dimension, drawn from 26 categories in the manifesto analysis. Again this shows a rightward shift by all but SF, with again, no obvious broadening of the gap between left and right parties, and FF and FG virtually indistinguishable. There was no change in importance.

\section{$<<$ INSERT FIGURE 3 ABOUT HERE $>>$}

\section{Conclusion}

This paper explores the 2011 election in Ireland, which was fought in the immediate aftermath of a 'bailout' made necessary by a major fiscal and banking crisis. In some respects the election overturned the traditional party system. This provides an extreme case of poor economic performance under the incumbent government, made more stark by the fact that the main incumbent party had been in office for 14 years. The 
central question was how well we can understand the result in these terms, as a classic case of retrospective voting. It appears to be a good illustration of economic voting: when the economy appeared to be in good shape the government was returned, and when it was performing very poorly, and it was very sick indeed in 2011, the government was punished. There is, however, no clear sign in this analysis that it was the variation in economic evaluations in 2011 as such that mattered, perhaps because there was such widespread agreement that matters were critical. More important were the perceptions of accountability and the assessment of the alternative. This approach also does tell us much about the performance of the other parties in the system and why FG seems to capitalise best on FF's collapse. More general models incorporating leaders not surprisingly perform better without telling us quite why the earthquake was so devastating.

We also explored the possibility that the crisis prompted some change from an election driven by the choice of the most competent party, to one driven by a concern for what a party might do, a shift to positional voting away from valence voting. One possibility was that the growth in the vote for parties of the left seen in 2011 was directly attributable to the nature of the crisis, with more people adopting left wing positions. Indeed, to the extent that the crisis is an indictment of neo-liberal economic management, we might have expected some redefinition of Irish electoral competition. Again, there was little sign of this. The electorate, if anything, seemed to move to the right, and perceived parties - even left wing ones - as doing so too. We looked at a number of policy choices and preferences, most notably the tax/spend trade-off, but could find no sign that the electorate engaged with parties in these terms. These sorts of issues, or attitudes had at best a very weak relationship with vote choice in 2011, just as they did in earlier years. A possible exception is that a voter's own location of themselves on a left- right spectrum does relate strongly to vote choice, but it is argued here that the evidence suggests this is a placement that reflects vote as much as it determines it, with placement very weakly linked to issues.

We then considered two reasons why issue voting of this sort was so weak. The first is the importance of candidates rather than parties for many voters, an importance that is arguably linked more closely to the provision of real and imaginary benefits to an area than to a candidate's ideological position. Voters did seem to give more weight to 
parties this time, claiming that parties (and policy) were more important. However, more party-centred voters appear to be hardly more ideological than their counterparts.

We also looked at the supply side: were the parties offering a clear choice to the voters. The pattern here was generally in accord with voters' self-placements and assessments: parties moved to the right and the distance between them did not change significantly and arguably remained small. If voters did not vote in accordance with their views on taxing and spending, for instance, perhaps this was in part due to their chronic and understandable inability to distinguish what the parties were promising. This is in line with what LeDuc and Pammett (in press) call the "politics of discontent", where governing parties may be replaced without any serious discussion of the crisis (causes and solutions) in the campaign by all parties. They suggest this is partly because parties arrive at an implicit consensus on the direction of economic policy and do not formulate alternative economic policy solutions, but it can also be difficult to present clear alternatives to the voters when this has not been the norm in the past. Mair (1992) argued that the reasons for the weakness of the left in Ireland lay not with the weakness of industrialisation - hardly plausible now - not even with 'clientelism' - but rather with the unusual ability of FF to attract support across the social spectrum and with the strategy of the Labour Party to opt for a small share in government rather than continued opposition whenever it was offered. This state of affairs has served to sustain valence politics, particularly when the national cleavage that underlay the FF-FG division lost its salience. FF's dominance is unlikely to be repeated, but with a FG/Labour government in place, and FF/SF in opposition, there is little more clarity on offer as yet and the odds are that valence based voting will predominate over substance based positional voting for some time to come.

This analysis carried some implications for comparative research. Firstly, while it does provide a good example of economic voting, it shows clearly attribution is a most important element in voters' calculations, and here this helps to show how some voters rationalised their decision to stay with FF or switch to an alternative. In general this alternative was seen as better able to do a good job; those who blamed FF, but were not attracted by the alternative opted for 'third' parties and independents. Secondly, this case shows little sign that the current crisis has prompted any significant move towards a more policy salient vote. Perhaps there are features of 
Irish politics that have traditionally discouraged such a focus. If so, these have not changed markedly, and even if voters claim to be more party centred, those parties did little to identify their own policy responses clearly in the public mind. Of course the lack of change should be seen in the context of the timing of the election as the first one of the economic crisis. It was natural for voters to switch to parties that might be similar, but different: a familiar set of parties, who could not easily be blamed for the disaster. If there is little improvement before the next election, due in 2016, that might prompt a greater change, but even so the absence of a clear left and right element in government-opposition conflict suggests that even though the next election might see a high level of volatility, it will not be driven by stronger positional voting. 


\section{Bibliography}

Benoit, Kenneth, and Michael Laver. 2006. Routledge research in comparative politics Party policy in modern democracies. Milton Park, Abingdon, Oxon ; New York: Routledge.

Benoit, Kenneth, Michael Laver, Will Lowe, and Slava Mikhaylov. 2012. "How to scale coded text units without bias: A response to Gemenis." Electoral Studies 31(3): 605-608.

Campbell, Angus, Philip Converse, Warren Miller, and Donald E Stokes. 1960. The American Voter. Chicago: University of Chicago Press.

Carty, Xavier. 1983. Elections '82: What the papers said: an analysis of press coverage of the two 1982 general elections in the Republic of Ireland. Dublin: Able Press.

Clarke, Harold, David Sanders, Marianne C Stewart, and Paul F Whiteley. 2009. Performance Politics and the British Voter. Cambridge: Cambridge University Press.

Curtice, J, and S Holmerg. 2005. "Party leaders and party choice." In The European Voter, ed. J Thomassen. Oxford: Oxford University Press, p. 235-253.

Duch, Raymond, Harvey Palmer, and Christopher J Anderson. 2000. "Heterogeneity in Perceptions of National Economic Conditions." American Journal of Political Science 44: 863-881.

Evans, Geoffrey, and Robert Andersen. 2006. "The Political Conditioning of Economic Perceptions: Evidence from the 1992-97 British Electoral Cycle." Journal of Politics 68: 194-207.

Green, Donald, Bradley Palmquist, and Eric Schickler. 2002. Partisan Hearts and Minds: Political Parties and the Social Identities of Voters. New Haven, Conn.: Yale University Press.

Hardiman, Niamh, and Christopher T Whelan. 1994. "Values and Political Partisanship." In Values and Social Change in Ireland, ed. Christopher T Whelan. Dublin: Gill and Macmillan.

Higgins, Michael D. 1982. "The limits of clientelism: towards an assessment of Irish politics.” In Private Patronage and Public Power, ed. Christopher Clapham. London: Frances Pinter, p. 114-141.

Inglehart, Ronald, and Hans-Dieter Klingemann. 1976. "Party Identification, Ideological Preference, and the Left-Right Dimension among Western Mass Publics." In Party Identification and Beyond: Representations of Voting and Party Competition, eds. Ian Budge, Ivor Crewe, and Dennis Farlie. New York: Wiley. 
Kennedy, Fiachra, and Richard Sinnott. 2006. "Irish Social and Political Cleavage." In Irish Social and Political Attitudes, eds. John Garry, Niamh Hardiman, and Diane Payne. Liverpool: Liverpool University Press, p. 78-93.

Key, V O. 1966. The Responsible Electorate. New York: Vintage.

Komito, L, and M Gallagher. 2010. "The constituency role of Dáil deputies.” In Politics in the Republic of Ireland, eds. J Coakley and M Gallagher. New York: Routledge, p. 230-262.

LeDuc, L. and J. Pammett. "The Fate of Governing Parties in Times of Economic Crisis." Electoral Studies, in press.

Lowe, Will, Kenneth Benoit, Slava Mikhaylov, and Michael Laver. 2011. "Scaling Policy Preferences from Coded Political Texts." Legislative Studies Quarterly 36(1): 123-155.

Mair, Peter. 1992. "Explaining the absence of class politics in Ireland." In The development of industrial society in Ireland, eds. J. H. Goldthorpe and C. T. Whelan., p. 383-410.

. 2011. "The election in context." In How Ireland Voted 2011: The Full Story of Ireland's Earthquake Election, Basingstoke: Palgrave, p. 283-297.

Marsh, Michael. 2007. "Candidates or parties? Objects of electoral choice in Ireland." Party Politics 13(4): 500-527.

Marsh, Michael, and Kevin Cunningham. 2011. "A Positive Choice, or Anyone but Fianna Fáil?" In How Ireland Voted 2011: The Full Story of Ireland's Earthquake Election, eds. M Gallagher and Michael Marsh. Basingstoke: Palgrave, p. 172-202.

Marsh, Michael, and Slava Mikhaylov. 2012. "Economic voting in a crisis: The Irish election of 2011." Electoral Studies 31(3): 478-484.

Marsh, Michael, Richard Sinnott, John Garry, and Fiachra Kennedy. 2008. The Irish Voter: The Nature of Electoral Competition in the Republic of Ireland. Manchester: Manchester University Press.

Marsh, Michael, and James Tilley. 2010. "The Attribution of Credit and Blame to Governments and Its Impact on Vote Choice." British Journal of Political Science 40(1): 115-134.

Miller, W, and M Shanks. 1996. The New American Voter. Cambridge: Harvard University Press.

Powell, G Bingham, and Guy D Whitten. 1993. "A Cross-National Analysis of Economic Voting: Taking Account of the Political Context." American Journal of Political Science 37: 391-414. 
Sacks, Paul. 1976. The Donegal Mafia: an Irish Political Machine. New Haven, Conn. and London: Yale University Press.

Sinnott, Richard. 1995. Irish Voters Decide: Voting Behaviour in Elections and Referendums since 1918. Manchester: Manchester University Press.

Stokes, D. E. 1963. "Spatial Models of Party Competition.” American Journal of Political Science 57(2): 368-377.

Suiter, Jane, and David Farrell. 2011. "The Parties' Manifestos." In How Ireland Voted 2011: The Full Story of Ireland's Earthquake Election, Basingstoke: Palgrave.

Weeks, L. 2009. "We don't like (to) party. A typology of Independents in Irish political life, 1922-2007." Irish Political Studies 24(1): 1-27. 
Table 1. Responsibility for the crisis

\begin{tabular}{|c|c|c|c|c|c|c|}
\hline & Not at all & A little & Moderately & Very & Extremely & Mean \\
\hline & 1 & 2 & 3 & 4 & 5 & \\
\hline Bankers & 1 & 1 & 5 & 15 & 77 & 4.7 \\
\hline $\begin{array}{l}\text { Department of Finance } \\
\text { and Irish Central Bank }\end{array}$ & 2 & 3 & 9 & 28 & 58 & 4.3 \\
\hline The Irish Government & 1 & 7 & 14 & 33 & 45 & 4.1 \\
\hline $\begin{array}{l}\text { International economic } \\
\text { situation }\end{array}$ & 3 & 11 & 27 & 32 & 27 & 3.7 \\
\hline The European Union & 6 & 16 & 34 & 26 & 17 & 3.3 \\
\hline Membership of the euro & 15 & 23 & 27 & 19 & 17 & 3 \\
\hline
\end{tabular}

Note: In the past few years the economy has been in recession. How responsible, if at all, are each of the following for the poor economic conditions of the past two years? Extremely responsible, Very responsible, moderately responsible, A little responsible, not at all responsible. 
Table 2. Elements of Economic voting

\begin{tabular}{|c|c|c|c|}
\hline & 2002 & 2007 & 2011 \\
\hline \multicolumn{4}{|l|}{ Economy: } \\
\hline Got A Lot Worse & 3 & 3 & 78 \\
\hline Got A Little Worse & 7 & 9 & 16 \\
\hline Stayed The Same & 10 & 18 & 4 \\
\hline Got A Little Better & 40 & 42 & 2 \\
\hline Got A Lot Better & 40 & 28 & * \\
\hline \multicolumn{4}{|l|}{ Credit/Blame } \\
\hline Mainly due to policies of the government & 64 & 66 & 82 \\
\hline \multicolumn{4}{|l|}{ Alternative } \\
\hline Better & 19 & 11 & 42 \\
\hline Same & 81 & 62 & 29 \\
\hline Worse & 81 & 27 & 29 \\
\hline
\end{tabular}

Note: Thinking back over the last four years - the lifetime of the 2007 to 2011 Fianna Fáil/PD/Green government - would you say that the ECONOMY in Ireland over that period of time got a lot better; a little better; stayed the same; got a little worse; or got a lot worse? Do you think this was MAINLY due to the policies of that government or NOT MAINLY DUE to the policies of that government? Would a Fine Gael/Labour coalition have handled the economy better in the past? [This is the 2011 formulation. 2007 and 2002 are different only in terms of lifetime and government composition, except for the 2002 variation below.]

In 2002 the final question was: Would any other party have performed better? This is coded here just for FG and/or Labour.

* Less that $0.5 \%$ 
Table 3. Average marginal effects of economic vote model with party attachment: standard errors in brackets.

\begin{tabular}{|c|c|c|c|c|}
\hline & & 2002 & 2007 & 2011 \\
\hline \multirow[t]{6}{*}{ Fianna Fail } & Economy & $-0.030^{*}$ & -0.024 & $-0.059 * * *$ \\
\hline & & $(0.017)$ & $(0.021)$ & $(0.020)$ \\
\hline & Responsibility & $0.129 * * *$ & $0.120 * * *$ & $-0.131 * * *$ \\
\hline & & $(0.021)$ & $(0.028)$ & $(0.026)$ \\
\hline & Alternative & $-0.240 * * *$ & $-0.216 * * *$ & $-0.072 * * *$ \\
\hline & & $(0.028)$ & $(0.042)$ & $(0.017)$ \\
\hline \multirow[t]{6}{*}{ Fine Gael } & Economy & 0.009 & 0.012 & 0.048 \\
\hline & & $(0.014)$ & (0.019) & $(0.047)$ \\
\hline & Responsibility & $-0.040 * *$ & $-0.052 *$ & 0.051 \\
\hline & & (0.019) & $(0.027)$ & $(0.033)$ \\
\hline & Alternative & $0.190 * * *$ & $0.108 * *$ & $0.136 * * *$ \\
\hline & & $(0.03)$ & $(0.046)$ & $(0.025)$ \\
\hline \multirow[t]{6}{*}{ Labour } & Economy & $0.016^{*}$ & 0.004 & -0.053 \\
\hline & & $(0.009)$ & (0.014) & $(0.032)$ \\
\hline & Responsibility & -0.021 & -0.002 & $0.048^{*}$ \\
\hline & & $(0.013)$ & $(0.02)$ & $(0.025)$ \\
\hline & Alternative & $0.085^{* * *}$ & $0.104^{* * *}$ & $0.034^{*}$ \\
\hline & & $(0.021)$ & $(0.039)$ & $(0.020)$ \\
\hline \multirow[t]{6}{*}{ Sinn Fein } & Economy & $0.011^{*}$ & 0.012 & -0.003 \\
\hline & & $(0.007)$ & (0.009) & $(0.027)$ \\
\hline & Responsibility & -0.006 & $-0.026 *$ & 0.005 \\
\hline & & $(0.010)$ & $(0.014)$ & (0.019) \\
\hline & Alternative & $-0.018^{*}$ & -0.022 & $-0.041 * * *$ \\
\hline & & $(0.011)$ & $(0.017)$ & $(0.014)$ \\
\hline \multicolumn{2}{|l|}{ Log Likelihood } & -1947 & -1096 & -1926 \\
\hline \multicolumn{2}{|l|}{ Pseudo R2 } & 0.199 & 0.197 & 0.167 \\
\hline \multicolumn{2}{|c|}{ Pseudo R2: party attachment only } & 0.165 & 0.177 & 0.139 \\
\hline \multicolumn{2}{|c|}{ Observations } & 1,767 & 983 & 1,578 \\
\hline
\end{tabular}

Note: Standard errors in parentheses $* * * p<0.01,{ }^{* *} p<0.05,{ }^{*} p<0.10$. Effects of party attachment and effect on Others not shown. 
Table 4. Average marginal effects of policy preference model with party attachment: standard errors in brackets.

\begin{tabular}{|c|c|c|c|c|c|}
\hline \multirow{13}{*}{$\overline{\text { Fianna Fail }}$} & & 2002 & 2007 & 2011 & 2011 \\
\hline & Tax/spend & -0.002 & 0.007 & 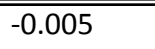 & \\
\hline & & $(0.005)$ & $(0.006)$ & $(0.004)$ & \\
\hline & More regulation & 0.002 & -0.003 & $-0.005^{*}$ & $-0.006 *$ \\
\hline & & $(0.004)$ & $(0.006)$ & $(0.003)$ & $(0.003)$ \\
\hline & Ordinary people get fair share [disagree] & 0.007 & $0.017^{* *}$ & 0.004 & 0.006 \\
\hline & & $(0.006)$ & $(0.008)$ & $(0.005)$ & $(0.005)$ \\
\hline & Nothing wrong with some being richer [agree] & 0.008 & 0.013 & $0.012 * *$ & $0.014 * *$ \\
\hline & & $(0.006)$ & $(0.01)$ & $(0.006)$ & $(0.006)$ \\
\hline & More private ownership & & & & 0.003 \\
\hline & & & & & $(0.003)$ \\
\hline & Tax/spend (2011) & & & & 0.002 \\
\hline & & & & & $(0.004)$ \\
\hline \multirow[t]{12}{*}{ Fine Gael } & Tax/spend & 0.003 & 0.001 & 0.003 & \\
\hline & & $(0.004)$ & $(0.006)$ & $(0.006)$ & \\
\hline & More regulation & 0.001 & -0.000 & $0.009 * *$ & $0.009 *$ \\
\hline & & $(0.004)$ & $(0.005)$ & $(0.004)$ & $(0.005)$ \\
\hline & Ordinary people get fair share [disagree] & -0.000 & -0.011 & 0.011 & 0.012 \\
\hline & & $(0.005)$ & $(0.007)$ & $(0.007)$ & $(0.007)$ \\
\hline & Nothing wrong with some being richer [agree] & -0.001 & -0.011 & $0.021 * *$ & $0.024^{* * *}$ \\
\hline & & $(0.005)$ & $(0.008)$ & $(0.009)$ & $(0.009)$ \\
\hline & More private ownership & & & & -0.004 \\
\hline & & & & & $(0.005)$ \\
\hline & Tax/spend (2011) & & & & -0.001 \\
\hline & & & & & $(0.006)$ \\
\hline \multirow[t]{12}{*}{ Labour } & Tax/spend & 0.003 & 0.000 & 0.003 & \\
\hline & & $(0.003)$ & $(0.004)$ & $(0.005)$ & \\
\hline & More regulation & -0.002 & -0.004 & $-0.006^{*}$ & -0.006 \\
\hline & & $(0.003)$ & $(0.004)$ & $(0.004)$ & $(0.004)$ \\
\hline & Ordinary people get fair share [disagree] & -0.001 & 0.006 & 0.005 & 0.002 \\
\hline & & $(0.004)$ & $(0.005)$ & $(0.006)$ & $(0.006)$ \\
\hline & Nothing wrong with some being richer [agree] & -0.004 & 0.009 & $-0.021 * * *$ & $-0.021 * * *$ \\
\hline & & $(0.004)$ & $(0.007)$ & $(0.007)$ & $(0.007)$ \\
\hline & More private ownership & & & & -0.001 \\
\hline & & & & & $(0.004)$ \\
\hline & Tax/spend (2011) & & & & 0.004 \\
\hline & & & & & $(0.005)$ \\
\hline \multirow[t]{12}{*}{ Sinn Fein } & Tax/spend & 0.000 & -0.004 & $-0.007^{* *}$ & \\
\hline & & $(0.002)$ & $(0.003)$ & $(0.003)$ & \\
\hline & More regulation & 0.001 & -0.001 & 0.002 & 0.003 \\
\hline & & $(0.002)$ & $(0.002)$ & $(0.003)$ & $(0.003)$ \\
\hline & Ordinary people get fair share [disagree] & -0.002 & $-0.013^{* * *}$ & -0.007 & $-0.008^{*}$ \\
\hline & & $(0.003)$ & $(0.005)$ & $(0.004)$ & $(0.004)$ \\
\hline & Nothing wrong with some being richer [agree] & 0.002 & $-0.008 * *$ & -0.008 & $-0.013 * *$ \\
\hline & & $(0.003)$ & $(0.004)$ & $(0.005)$ & $(0.005)$ \\
\hline & More private ownership & & & & -0.001 \\
\hline & & & & & $(0.003)$ \\
\hline & Tax/spend (2011) & & & & -0.005 \\
\hline & & & & & $(0.003)$ \\
\hline \multicolumn{2}{|c|}{ Log Likelihood } & -1931 & -1084 & -1662 & -1639 \\
\hline \multicolumn{2}{|c|}{ Pseudo R2 } & 0.163 & 0.181 & 0.158 & 0.153 \\
\hline \multicolumn{2}{|c|}{ Pseudo R2: party attachment only } & 0.161 & 0.167 & 0.146 & 0.14 \\
\hline \multicolumn{2}{|c|}{ Observations } & 1,670 & 955 & 1,351 & 1,326 \\
\hline
\end{tabular}

Note: Standard errors in parentheses $* * * \mathrm{p}<0.01, * * \mathrm{p}<0.05, * \mathrm{p}<0.10$. 
Table 5. LR mean position of parties, 2002-11

\begin{tabular}{l|rrr|rrr} 
& \multicolumn{3}{c|}{ Self-placement by party's voters } & \multicolumn{3}{c}{ Voters' placement of each party } \\
\cline { 2 - 5 } & 2002 & 2007 & 2011 & 2002 & 2007 & 2011 \\
\hline \hline FF & 6.4 & 6.4 & 6.6 & 6.4 & 6.6 & 6 \\
PD & 6.2 & 6.1 & na & 6.2 & 6.2 & na \\
FG & 6 & 5.8 & 6.6 & 6 & 6.1 & 6.8 \\
Ind/Other & 5.4 & 5.3 & 5.5 & na & na & na \\
Labour & 4.6 & 4.6 & 5.4 & 3.7 & 4.1 & 4.5 \\
Green & 4.4 & 4.4 & 5.3 & 4.4 & 4.4 & 4.2 \\
SF & 4.4 & 4.6 & 4.6 & 3.1 & 3.5 & 2.9
\end{tabular}


Figure 1. Distribution of tax/spend preferences

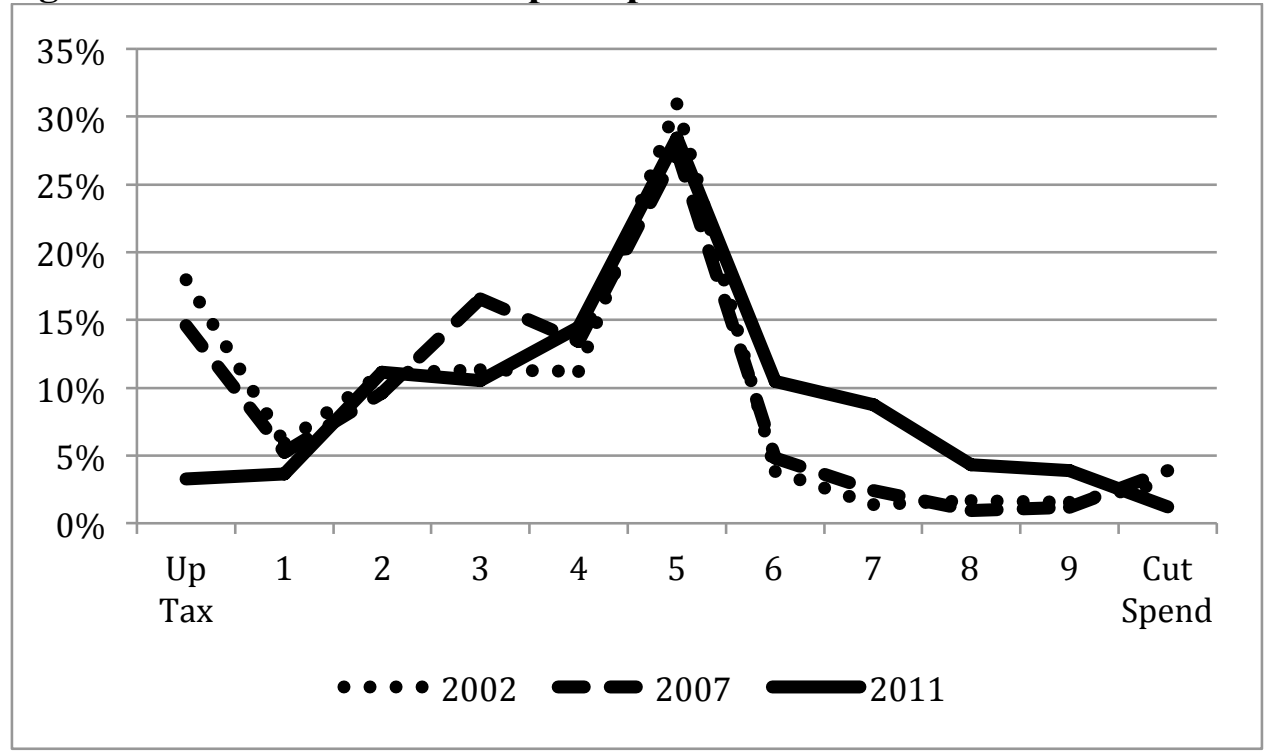

Note: I would like you to look at the scale from 0 to 10 below. A ' 0 ' means government should CUT TAXES A LOT and SPEND MUCH LESS on health and social services, and ' 10 ' means government should INCREASE TAXES A LOT and SPEND MUCH MORE on health and social services. Where would you place yourself in terms of this scale? This scale has been reversed in the graph here, so that 'left' is 0 and 'right' is at 10. 
Figure 2. Left right self-placement

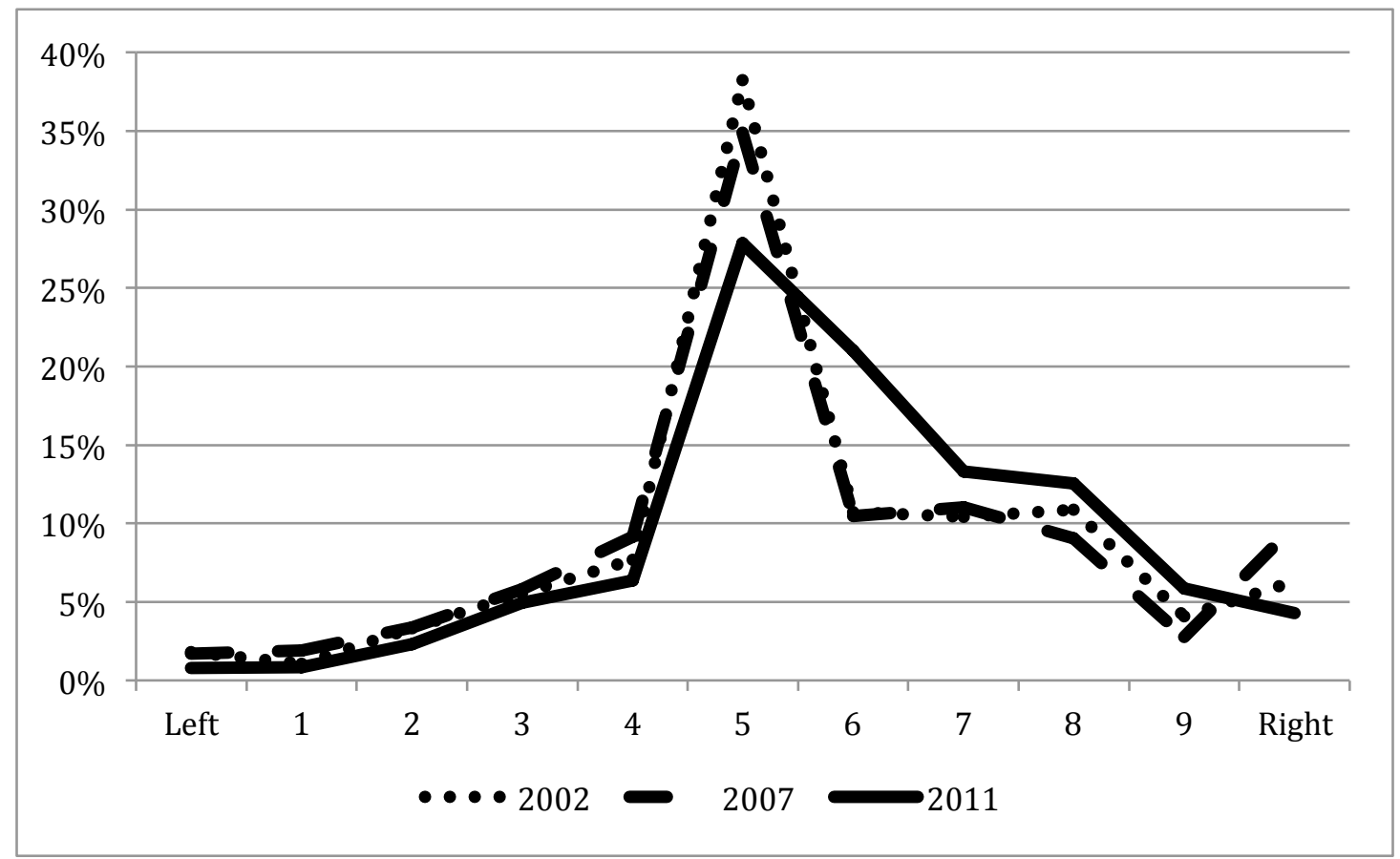

Note: In politics people sometimes talk of left and right. Where would you place yourself on a scale from 0 to 10 where 0 means the left and 10 means the right? 
Figure 3: Positions of main parties and dimensional importance

\section{A: State involvement in economy}
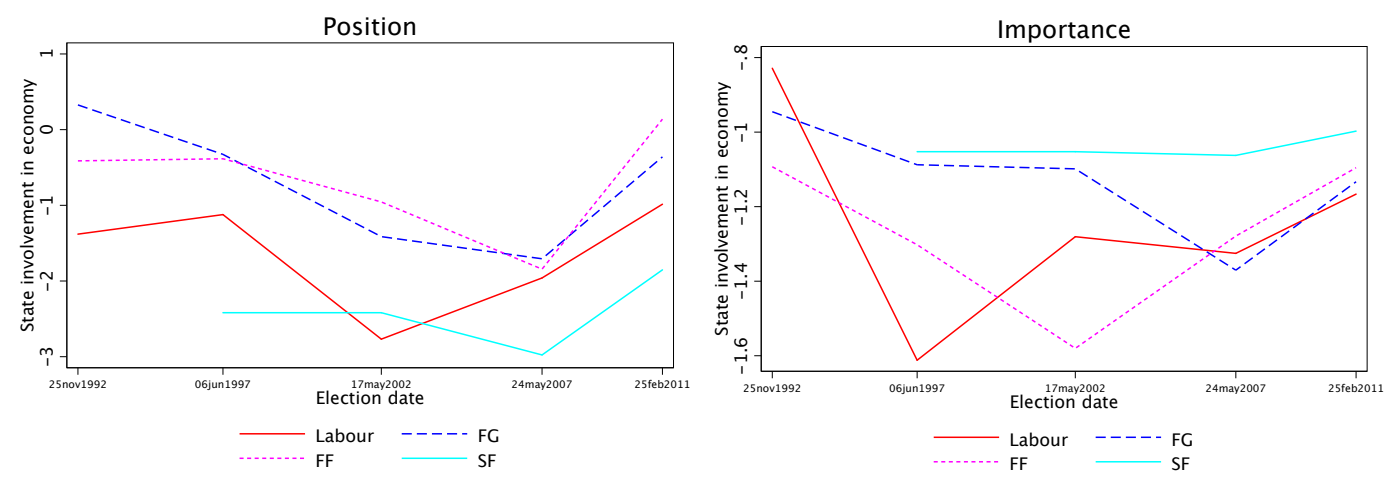

B: State-provided services
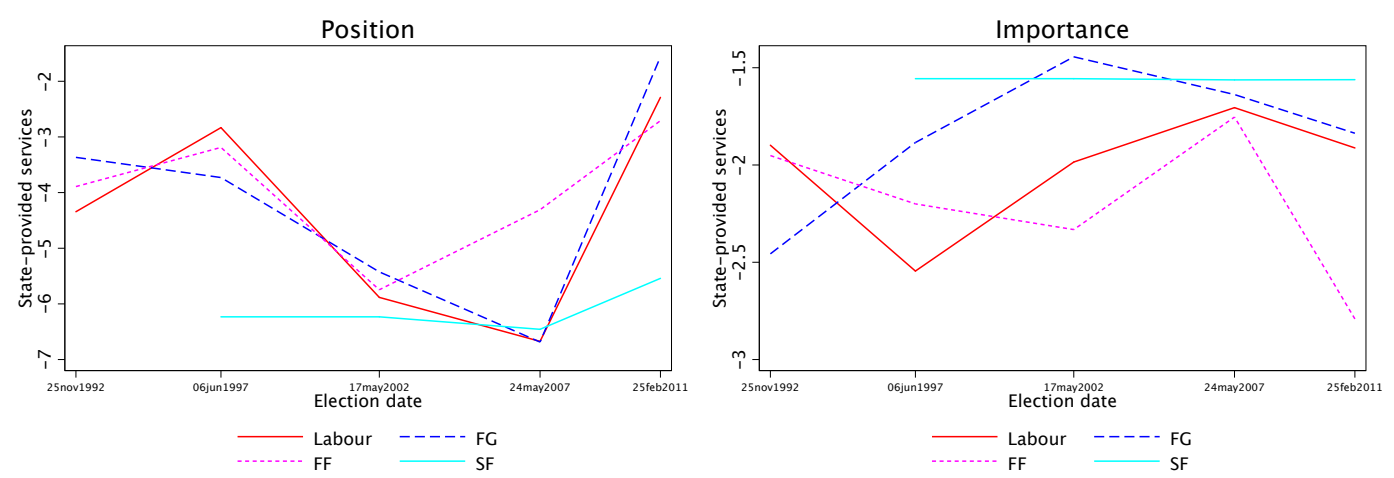

C: General left-right
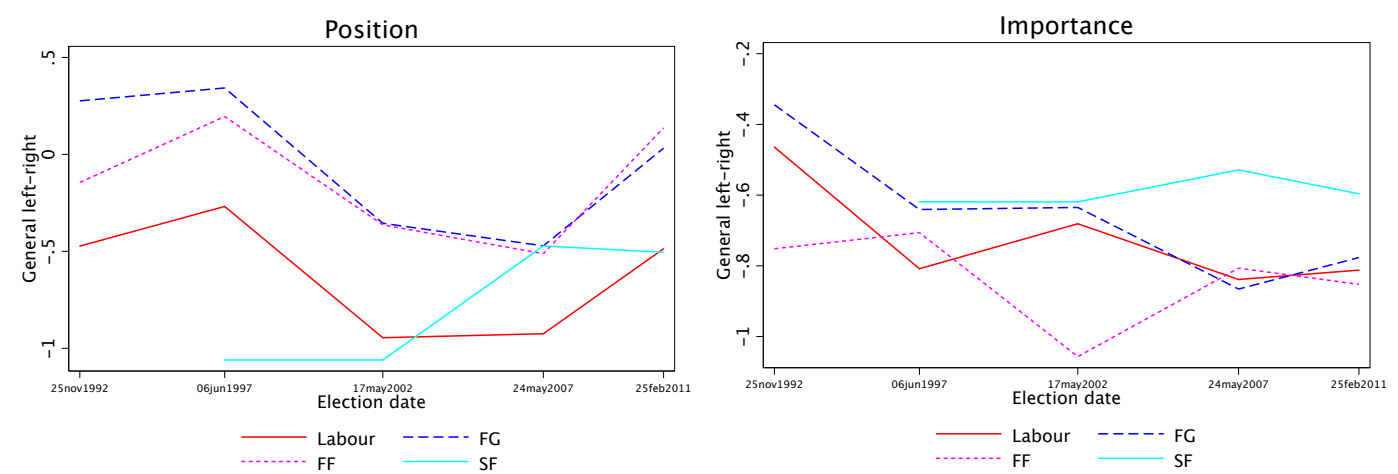

\footnotetext{
${ }^{1}$ This is the combined vote of the centrist left Labour (19.4 per cent), the nationalist left Sinn Fein (SF) (9.9 per cent) and the United Left Alliance (2.7 per cent). If we add the Green Party (1.8 per cent) it would rise to 32.8 per cent. In 2007 these combined parties won only 21.6 per cent, with the Greens contributing 4.6 per cent. ${ }^{2}$ This was a post-election study of 1,853 respondents with interviewing completed a few weeks after the election. Households were selected using a random route method starting from [300] locations drawn from all 43 constituencies. Interviewees were chosen within households to fit demographic quotas.
} 
${ }^{3} \mathrm{We}$ included party identification to allow for the possibility that many voters would view the world through partisan spectacles (Campbell et al. 1960; Duch, Palmer, and Anderson 2000; see also Evans and Andersen 2006 for a stronger critique). For a contrary view see Green et al. (2002). Partisanship - measured by the question asking are you close to any political party - is very low, with only about a quarter of voters admitting to such an identification, and dropping to 20 per cent in 2011, as FF partisans vanished. Clearly, this measure cannot be seen as wholly independent of recent experiences. We opted for a simple model without interactions (c.f. Marsh and Tilley 2010) because including the responsibility measure and the assessment of an alternative ran the risk of overcorrecting for a partisan bias.

As we see, the partisanship variables seem to be doing most of the work. Without them the pseudo $\mathrm{R}^{2}$ is much lower, $.08, .04$ and .05 respectively.

${ }^{4}$ The parameters of multinomial models are not directly interpretable but their significance can be immediately discerned. Much of our discussion below specifically revolves around the analysis of significance of individual coefficients (and overall model performance). However, in multinomial models coefficients can be calculated only in relation to the baseline category (Fine Gael in our case), while we would prefer to have the effects for all parties. This can be achieved by changing the focus from the logit coefficients to the marginal effects that can be calculated for all categories (parties). The marginal effects in multinomial models capture the impact of a change in the predictor on the probability of observing each of several alternative outcomes. The table presents average marginal effects (AMEs) for each of the alternatives with corresponding uncertainty estimates. The reported results are derivatives (or discrete first-differences for factor variables) of the response with respect to the key predictors, i.e. it captures a change in the response for a change in the predictor.

${ }^{5}$ All other parties are included with Independents as Others. The numbers voting for each of these are too small to analyse usefully in this manner. Independents are a very disparate group and we have not shown the independents/others effects, but they are generally not significant.

${ }^{6}$ Full results from this estimation are not shown here to preserve space. They are available from the authors upon request.

${ }^{7}$ A special feature of 2011 that attracted comment was the degree of anger felt by many voters as they were let down by the government and the financial elite, and politicians in general, with large salaries and generous expenses and very comfortable pensions and severance payments. On a scale of $1-5$, where 5 is 'extremely angry' the median voter was at 4: very angry at "how things were going in the country these days". Including this emotion adds only marginally to the fit of the models run above, but does suggest SF and Independent voters were even angrier than those of FG and Labour.

${ }^{8}$ The results are available from the authors upon request.

${ }^{9}$ I would like you to look at the scale from 0 to 10 below. A ' 0 ' means government should CUT TAXES A LOT and SPEND MUCH LESS on health and social services, and '10' means government should INCREASE TAXES A LOT and SPEND MUCH MORE on health and social services. Where would you place yourself in terms of this scale? This scale has been reversed in the discussion here, so that 'left' is 0 and 'right' is at 10 .

In 2011, arguably, the choice was not so much one between increasing tax or cutting spending, but how much tax should increase and how far spending should be cut. For 
this reason the INES asked a second question: I would like you to look at the scale from 0 to 10 on this card. A ' 0 ' means government should MAINTAIN TAXES and SPEND LESS on health and social services, and ' 10 ' means government should INCREASE TAXES A LOT and SPEND THE SAME on health and social services. Where would you place yourself in terms of this scale.

There is very little difference in either the distribution, or the effects on vote between these two wordings.

${ }^{10}$ We find much the same picture if we look at another measure designed to tap positions on a left right scale. There was an increase in support for more rather than less regulation in 2011, for instance, although there was also an increase for private rather than public enterprise.

${ }^{11}$ Full results are available from authors upon request.

${ }^{12}$ Full results are available from authors upon request.

${ }^{13}$ A similar analysis was carried out on the 1990 World Values study, but with different measures and results that suggested bigger differences between parties than we find here: see Hardiman and Whelan (1994).

${ }^{14}$ This was the final wave of a five-wave study, and even though it was supplemented to achieve a more representative sample, it is likely that the voters in 2007 were more sophisticated than those in 2002 or 2011.

${ }^{15}$ Such self-reporting may be considered unreliable, and may reflect a perception that parties should be more important rather than real motivation. However, there is separate evidence that more voters did give a priority to parties. Those voting a 'straight ticket' - giving a preference to all candidates for one party before those of a second party, did rise in 2011. This comes from the mock ballots filled in by election study respondents. (For a discussion of this method see Marsh et al., 2008.) Moreover, those who said they were more party centred did fill in their ballots in a more party centred way. Using the combined measure above, only 34 per cent of candidatecentred voters cast a straight ticket compared with 55 per cent of party-centred voters. Comparable percentages for 2002 and 2007 are 23 and 58, and 27 and 58.

${ }^{16}$ For 2011 , Pseudo $\mathrm{R}^{2}$ is 0.028 and 0.019 for party and candidate centred voters respectively using the variables in Table 4 , column 3 without party attachment. If a behavioural measure (and the number of cases is necessarily smaller here) it is used, $\mathrm{R}^{2}$ for those voting a straight party ticket is 0.043 and 0.025 for those who do not. ${ }^{17}$ Lowe et al. (2011) define the 'right' side of the dimension State involvement in economy as a combination of positive reference to free enterprise, economic incentives, economic orthodoxy, welfare state limitations, and negative references to protectionism. The 'left' side is defined by positive references to market regulation, economic planning, protectionism, controlled economy, nationalisation, welfare state expansion, education expansion, and labour groups. Position on the dimension is then scaled as the empirical logit transform of the difference between right and left. Thus more negative positions reflect more 'leftist' positions.

${ }^{18}$ Lowe et al. (2011) define the 'right' side of the dimension State-provided services as a combination of positive reference to welfare state limitation, education provision limitation. The 'left' side is defined by positive references to welfare state expansion, and education provision expansion. Position on the dimension is then scaled as the empirical logit transform of the difference between right and left. Thus more positive positions reflect more 'rightist' positions.

${ }^{19}$ General left-right is a combination of 26 categories from manifesto analysis, capturing a variety of left and right issues. 